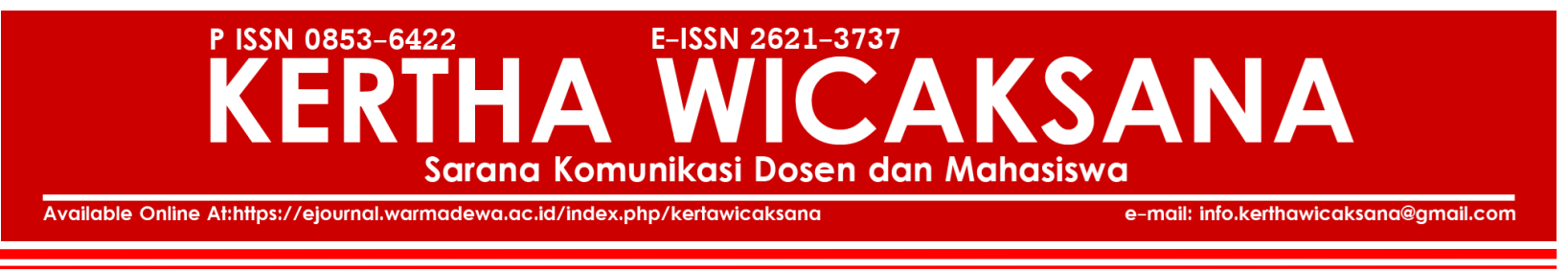

\title{
Legalitas Pemerintah Daerah Dalam Memberikan Bantuan Dana Kepada Perguruan Tinggi di Indonesia
}

\author{
Komang Satria Wibawa Putra \\ Universitas Pendidikan Nasional \\ komangsatria@undiknas.ac.id
}

Published: 30/07/2020

How To Cite:

Putra, K, S, W. (2020). Legalitas Pemerintah Daerah Dalam Memberikan Bantuan Dana Kepada Perguruan Tinggi di Indonesia. KERTHA WICAKSANA: Sarana Komunikasi Dosen dan Mahasiswa. 14 (2). Pp 103 - 109. https://doi.org/10.22225/kw.14.2.1845.103-109

\begin{abstract}
Abstrak
Keberadaan perguruan tinggi yang tersebar di seluruh wilayah Indonesia membutuhkan peran pemerintah daerah dalam memberikan bantuan dana. Pasal 83 ayat (2) Undang-Undang Pendidikan Tinggi menyebutkan bahwa pemerintah daerah dapat memberikan dukungan dana Pendidikan Tinggi yang dialokasikan dalam Anggaran Pendapatan dan Belanja Daerah. Norma di dalam pasal tersebut mengakibatkan multiinterpretasi terkait dengan kapan dan bagaimana cara pemerintah daerah memberikan bantuan dana. Sehingga rumusan masalah yang digunakan adalah 1) Bagiamanakah legalitas pemerintah daerah dalam mendanai perguruan tinggi di indonesia? 2) Bagaimana peran pemerintah daerah dalam memberikan dukungan dana kepada perguruan tinggi di Indonesia? Metode penelitian yang digunakan dalam penelitian ini yaitu metode penelitian hukum normatif. Hasil penelitian menunjukan bahwa Melihat posisi dari perguruan tinggi yang berada di lingkungan pemerintah daerah sebagai Aset Daerah, Partner Strategis dan Center of Excellent, menciptakan situasi \& kondisi yang sangat menguntungan bagi pemerintah daerah untuk bersinergi dengan perguruan tinggi. Selain itu arti kata dapat di dalam Pasal 83 ayat (2) Undang-Undang Pendidikan Tinggi diartikan sebagai situasi pemerintah daerah yang dalam mampu, sanggup ataupun bisa untuk memberikan bantuan dana kepada perguruan tinggi. Jika pemerintah daerah merasa belum sanggup, mampu ataupun bisa, maka alokasi dana kepada perguruan tinggi tersebut dapat tidak dilakukan. Kemudian kesanggupan tersebut dapat di perankan oleh pemerintah sebagai regulator, dinamisator dan fasilitator.
\end{abstract}

Kata Kunci: Dana, perguruan tinggi, pemerintah daerah

\begin{abstract}
The existence of tertiary institutions spread throughout Indonesia requires the role of local governments in providing financial assistance. Article 83 paragraph (2) of the Higher Education Law provides that regional governments can provide support for Higher Education funds allocated in the Regional Revenue and Expenditure Budget. The norm in the article results in multiple interpretations related to when and how local governments provide financial assistance. So the formulation of the problem used is 1) How is the legality of the local government in funding tertiary institutions in Indonesia? 2) What is the role of local government in providing financial support to universities in Indonesia? The research method used in this study is the normative legal research method. The results showed that seeing the position of tertiary institutions within the local government environment as Regional Assets, Strategic Partners and the Center of Excellent, created very favorable situations and conditions for local governments to synergize with tertiary institutions. In addition, the meaning of the word can be in Article 83 paragraph (2) of the Higher Education Act is interpreted as a situation of local governments that are able, able or able to provide financial assistance to universities. If the regional government feels unable, able or able, then the allocation of funds to the tertiary institution may not be carried out. Then the ability can be played by the government as a regulator, dynamic and facilitator.
\end{abstract}

Keyword: Fund, college; regional goverment; 


\section{PENDAhuluan}

Indonesia adalah negara hukum sebagaimana yang tercantum di dalam Pasal 1ayat (3) UndangUndang Dasar Negara Republik Indonesia Tahun 1945 yang mengakibatkan segala tindakan individu, kelompok, warga negara serta lembaga negara harus tunduk pada perintah hukum, baik itu bersifat imperatif maupun alternatif (Fajjlurahman, 2019). Sebagai negara hukum dalam setiap produk hukumnya, baik itu yang sudah berlaku (ius constitutum) maupun yang akan belaku atau hukum yang dicita-citakan (ius constituendum) seyogyanya selaras dan sesuai dengan apa yang menjadi cita-cita bangsa Indonesia. Sebagaimana yang tercantum dalam Pembukaan Undang-Undang Dasar Negara Republik Indonesia Tahun 1945 alinea ke-IV yang mana salah satu cita-cita bangsa Indonesia adalah mencerdaskan kehidupan bangsa.

Langkah konkret yang bisa dilakukan negara dalam mencerdaskan kehidupan bangsa adalah membangun dan mengembangkan bidang pendidikan. Pendidikan merupakan pembangunan yang ditujukan untuk peningkatan kualitas manusia agar mampu bersaing, baik di tingkat lokal, nasional maupun internasional. Oleh karena, kualitas sumber daya manusia adalah modal bangsa untuk unggul dalam berbagai persaingan.

Perguruan Tinggi sebagai salah satu satuan pendidikan terakhir dalam pembangunan sumber daya manusia memiliki posisi dan peran yang strategis. Perguruan tinggi memiliki peranan yang penting untuk mencetak sumber daya manusia yang bersaing (Nulhaqim, Heryadi, Pancasilawan, \& Fedryansyah, 2016). Berdasarkan Pasal 1 angka 6 Undang-Undang Nomor 12 tahun 2012 tentang Pendidikan Tinggi yang selanjutnya disebut Undang-Undang Dikti menyebutkan bahwa Perguruan Tinggi adalah satuan pendidikan yang menyelenggarakan Pendidikan Tinggi, sedangkan Pendidikan Tinggi adalah jenjang pendidikan setelah pendidikan menengah yang mencakup program diploma, program sarjana, program magister, program doktor, dan program profesi, serta program spesialis, yang diselenggarakan oleh perguruan tinggi berdasarkan kebudayaan bangsa Indonesia (Pasal 1 angka 3 Undang-Undang Pendidikan Tinggi).

Perguruan tinggi di Indonesia terklasterisasi atau terbagi menjadi dua, yakni Perguruan Tinggi Negeri dan Perguruan Tinggi Swasta.
Sebagaimana yang tercantum dalam Pasal 1 angka 6 dan 7 Undang-Undang Pendidikan Tinggi menyebutkan bahwa Perguruan Tinggi Negeri yang selanjutnya disingkat PTN adalah perguruan tinggi yang didirikan dan/atau diselenggarakan oleh Pemerintah, sedangkan Perguruan Tinggi Swasta yang selanjutnya disingkat PTS, adalah Perguruan Tinggi yang didirikan dan/atau diselenggarakan oleh masyarakat. Letak perbedaan mendasar antara PTN dan PTS adalah terletak pada pendiriannya dan/atau pada penyelenggaraan perguruan tinggi tersebut.

Keberadaan perguruan tinggi, baik itu PTN maupun PTS tersebar di seluruh wilayah Indonesia, baik di Kabupaten/Kota maupun di Provinsi. Akan tetapi, meskipun PTN maupun PTS tersebut berdomisili di kabupaten/kota dan/ atau provinsi, mereka bukanlah aset pemerintah daerah. PTN merupakan aset pemerintah pusat, sedangkan PTS merupakan asset publik atau masyarakat sebagai penyelenggara dalam bentuk badan hukum seperti yayasan, perkumpulan dan sebutan lainnya. Peran pemerintah dalam mengembangkan Pendidikan sampai saat ini sudah terklatserisasi menjadi dua yaitu, Pemerintah Pusat memiliki kewajiban memfasilitasi Pendidikan Tinggi sedangkan pemerintah daerah memiliki kewajiban memfasilitasi pendidikan dasar dan menengah.

Kendatipun demikian, mahasiswa dan lulusan PTN dan PTS merupakan bagian yang tidak terpisahkan dengan aset pemerintah, termasuk pemerintah daerah. Terkhusus untuk PTS, kendatipun bukan milik pemerintah baik pusat maupun daerah tetapi peran serta dalam peningkatan kualitas lebih dominan dibandingkan peran PTN. Data menunjukan jumlah PTN di Indonesia yaitu, 397 PTN yang terbagi menjadi 56 Akademi, 139 Politeknik, 55 Sekolah Tinggi, 57 Institut, 83 Universitas, Akademi Komunitas 7. Lalu jumlah PTS di Indonesia yaitu, 4244 PTS yang terbagi menjadi 846 Akademi, 172 Politeknik, 2448 Sekolah Tinggi, 188 Institut, 559 Universitas, 31 Akademi Komunitas. Jumlah PTN tidak sampai $10 \%$ dibanding dari jumlah PTS. (https://pddikti.kemdikbud.go.id/pt)

Begitu besar peran lembaga perguruan tinggi dalam mengembangkan dan meningkatkan kualitas sumber daya manusia. Bahkan lulusan dari perguruan tinggi (alumni) adalah aset dari pemerintah pusat maupun daerah menjadi tanggung jawab dan peran kedua belah pihak. 
Sehingga kontribusi dari kedua belah pihak baik itu pemerintah pusat maupun pemerintah daerah adalah bagian yang tak terpisahkan dengan pembangunan sumber daya manusia secara komprehensif.

Bila dilihat dari aspek yuridis, peran dan tanggung jawab pemerintah baik itu pusat maupun daerah dalam pengembangan serta memfasilitasi perguruan tinggi khususnya PTS belum memiliki kejelasan secara regulatif. Oleh karena itu, kendatipun PTS bukan merupakan asset pemerintah daerah, seyogyanya dapat diberikan bantuan pendanaan oleh pemerintah daerah sebagaimana yang teracantum dalam Pasal 83 ayat (2) Undang-Undang Pendidikan Tinggi yang menyebutkan bahwa pemerintah daerah dapat memberikan dukungan dana Pendidikan Tinggi yang dialokasikan dalam Anggaran Pendapatan dan Belanja Daerah.

Selanjutnya kata dapat dalam pasal 83 ayat (2) UU 122012 mengakibatkan multiinterpretasi terkait dengan sejauh mana bantuan yang dapat diberikan oleh pemerintah daerah. Hal ini berkaitan dengan standarisasi atau tolak ukur yang diberikan oleh Undang-Undang sehingga tidak menimbulkan kekaburan hukum dan menghambat implementasi dari Undang-Undang tersebut.

Permasalahan di atas patut untuk dikaji kebenarannya, oleh karena keberadaan perguruan tinggi di suatu daerah dapat pula menjadi salah satu indikator kemajuan daerah. Dampak positif dari keberadaan perguruan tinggi adalah turut mengembangkan dunia ekonomi mikro, termasuk berbagai usaha UMKM dan rumah kost. Kondisi tersebut mencerminkan betapa besar peran pendidikan, termasuk pendidikan tinggi dalam meningkatkan derajat pendidikan masyarakat dan kualitas sumber daya manusia di daerah tersebut.

Penduduk besar dengan kualitas tinggi merupakan modal dasar pembangunan, begitu sebaliknya penduduk besar bila kualitasnya rendah, maka dapat menjadi beban pembangunan bagi suatu daerah. Oleh karena sangat penting dan strategis untuk meningkatkan kualitas pendidikan di berbagai satuan dan jenjang pendididkan termasuk perguruan tinggi.

Berkaitan dengan hal tersebut di atas, maka yang menjadi fokus kajian dalam tulisan ini dimakakah posisi dan peran pemerintah daerah dalam memfasilitasi lembaga perguruan tinggi jika dilihat dari perspeketif UU No. 12 Tahun
2012 Tentang Pendidikan Tinggi.

\section{METODE}

Penelitian ini menggunakan jenis penelitian yuridis normatif, karena penelitian ini beranjak dari adanya kekaburan norma yang diatur di dalam Undang-Undang Pendidikan Tinggi Pasal 83 ayat (2) terkait dengan dukungan dana Perguruan Tinggi yang dapat diberikan oleh pemerintah daerah yang dialokasikan dalam Anggaran Pendapatan dan Belanja Daerah. Pendekatan yang digunakan dalam peneltian ini adalah pendekatan undang-undang (statute approach) (Marzuki, 2005). yaitu dengan menganalisis peraturan perundang-undangan yang terkait dengan Pendidikan Tinggi serta peraturan perundang-undangan yang terkait dengan Pemerintahan Daerah khususnya UndangUndang Nomor 23 Tahun 2014 yang selanjutnya disebut Undang-Undang Pemerintah Daerah. Teknik pengumpulan data dalam penelitian ini dilakukan dengan cara mengumpulkan bahan hukum primer yang terkait dengan pokok persoalan yang diteliti. Kemudian diklasifikasikan menurut kelompok sesuai dengan hierarkhi peraturan perundang-undangan di Indonesia. Untuk bahan hukum sekunder dan bahan hukum tersier digunakan teknik dokumentasi secara kepustakaan.

Analisis bahan hukum penelitian ini dilakukan secara yuridis dogmatis. Dogma-dogma hukum yang telah dikumpulkan dari bahan hukum primer, sekunder dan tersier secara sistematis dirangkum dalam bentuk draft data komputer maupun arsip sehingga akan lebih mudah untuk dianalisis.

\section{III.HASIL DAN PEMBAHASAN}

\section{Legalitas Pemerintah Daerah dalam Mendanai Perguruan Tinggi di Indonesia}

Peningkatan kualitas sumber daya manusia melalui pendidikan seperti di perguruan tinggi tidak bisa dilepaskan dengan ketersediaan tiga (3) komponen utama yakni 1. Dana, 2. Orang, 3. Alat. Keterbatasan ketiga komponen tersebut relatif sulit membangun sebuah perguruan tinggi yang menghasilkan sumber daya manusia berkualitas. Komponen terpenting dari ketiga tersebut adalah dana, sebab ketersediaan dana akan mampu meningkatkan kualitas orang atau SDM yang menjadi penggerak kampus, begitu juga dengan ketersediaan dana akan mampu memenuhi kebutuhan alat atau infrastruktur yang dibutuhkan perguruan tinggi 
Umumnya pendanaan perguruan tinggi bersumber dari badan penyelenggara, masyarakat dan pihak ketiga yang secara sukarela bersedia membantu lembaga pendidikan tinggi demi peningkatan kualitas. Posisi pemerintah daerah turut serta membantu pendanaan terhadap perguruan tinggi adalah sebagai pihak ketiga.

Menurut Undang-Undang Pendidikan Tinggi, kendatipun pemerintah daerah tidak berkewajiban dalam penngembangan perguruan tinggi, serta hanya memiliki kewajiban untuk bertanggung jawab kepada pendidikan menengah dan pendidikan dasar untuk provinsi dan kabupaten/ kota, namun kata dapat membantu dalam pasal 83 ayat (2) Undang-Undang Pendidikan Tinggi, bisa dilakukan oleh pemerintah daerah provinsi dan kabupaten/kota dengan dasar pertimbangan seperti berikut ini;

\section{Perguruan tinggi sebagai aset daerah}

Perguruan tinggi yang berada di wilayah provinsi dan kabupaten/kota langsung ataupun tidak langsung telah menjadi bagian dari aset daerah. Oleh karena itu, jika pemerintah daerah membantu perguruan tinggi adalah bagian dari rasa memiliki dan bertanggung jawab pemrintah daerah terhadap keberadaan lembaga pendidikan tinggi di wilayahnya.

Fakta menunjukan lulusan perguruan tinggi dominan menjadi sumber tenaga kerja di daerah tersebut. Baik dimanfaatkan oleh pemerintah maupun pihak swasta yang berkedudukan di daerah dimana perguruan tinggi itu berada;

\section{Perguruan tinggi sebagai partner strategis}

Keberadaan perguruan tinggi di suatu daerah telah menjadi partner strategis bagi pemerintah daerah, baik provinsi dan kabupaten/kota. Hal itu terlihat dari kerjasama sinergis antara pendidikan tinggi dengan pemerintah daerah dalam berbagai bidang. Seperti penelitian, penyusunan berbagai macam regulasi, sebagai tenaga kelompok ahli dan bekerja sama dalam melakukan pengabdian dengan masyarakat;

\section{Perguruan tinggi sebagai center of excellent}

Keberadaan perguruan tinggi di suatu daerah secara nyata memperkecil capital flight (pindahnya modal) ke daerah lain ataupun ke negara lain. Oleh karena lulusan sekolah menengah tidak pergi ke luar daerah/luar negeri untuk melanjutkan sekolah. Hal ini berarti tidak ada perpindahan dana akibat melanjutkan pendidikan ke luar daerah atau ke luar negeri.
Sebagai iluustrasi, jika seribu (1000) orang tamatan sekolah menengah melanjutkan studi ke perguruan tinggi luar daerah dengan rata-rata biaya perbulan 5 juta perorang berarti ada capital flight 5 miliyar perbulan dari daerah tersebut.

Pertahun berarti ada 60 Miliyar. Sebaliknya jika (1000) mahasiswa tersebut tidak pergi ke luar daerah dan melanjutkan di daerah asal, maka dana 60 miliyar tersebut berputar pada suatu daerah maka dampak ikutannya (multiflyer effect) terhadap tumbuhnya berbagai aktivitas (ekonomi \& sosial) sangat signifikan. Apalagi dengan keberadaan perguruan tinggi di suatu daerah dapat mendatangkan mahasiswa dari luar daerah. Sudah pasti dampak ekonomi dan sosial serta aktivitas lain sangatlah besar. Sehingga keberadaan perguruan tinggi benar-benar menjadi center of excellent suatu daerah.

Legalitas Pemerintah Daerah dalam memfasilitasi perguruan tinggi dapat dilihat dari sisi kewenangan pemda. Berwenangkah pemerintah daerah dalam memfasilitasi perguruan tinggi di wilayahnya. Sesuai dengan prinsip di dalam Hukum Administrasi Negara, pemerintah daerah dalam memutuskan suatu kebijakan wajib berdasar atas dasar hukum (Asas Legalitas).

Asas legalitas (legaliteits beginselen atau wetmatigheid van bestuur), merupakan asas yang menjadi pilar utama negara hukum. Atas dasar prinsip tersebut, wewenang pemerintahan berasal dari peraturan perundang-undangan atau hukum positif yang berlaku. Hukum administrasi mengenal cara untuk memperoleh wewenang pemerintah yaitu: (Winanrno \& Nur, 2008)

Kewenangan Atribut, yaitu berasal dari adanya pembagian kekuasaan oleh peraturan perundangundangan. Pelaksanaan kewenangan atributif dilakukan oleh pejabat atau badan yang tertera dalam peraturan dasarnya;

Kewenangan Delegatif, yaitu bersumber dari pelimpahan suatu organ pemerintahan kepada organ lain dengan dasar peraturan perundangundangan. Dalam hal kewenangan delegatif tanggung jawab dan tanggung gugat beralih kepada yang diberi wewenang tersebut dan beralih pada delegatari;

Kewenangan Mandat, yaitu kewenangan yang bersumber dari proses atau prosedur pelimpahan dari pejabat atau badan yang lebih tinggi kepada pejabat atau badan yang lebih rendah. Kewenangan mandat terdapat dalam hubungan rutin atasan dan bawahan, kecuali bila dilarang 
secara tegas.

Berdasarkan prinsip kewenangan di atas, kewenangan pemerintah daerah untuk dapat memberikan dukungan dana pendidikan tinggi yang dialokasikan dalam Anggaran Pendapatan dan Belanja Daerah adalah kewenangan atributif pemerintah daerah. Hal ini dikarenakan kewenangan pemerintah daerah tercantum di dalam pasal 83 ayat (2) Undang-Undang Pendidikan Tinggi yang menyebutkan bahwa Pemerintah Daerah dapat memberikan dukungan dana Pendidikan Tinggi yang dialokasikan dalam Anggaran Pendapatan dan Belanja Daerah. Tecantumnya norma tersebut di dalam peraturan perundang-undangan menjadikan kewenangan pemerintah daerah menjadi kewenangan atribusi disebabkan pemberian wewenang pemerintah oleh pembuat undang-undang kepada organ pemerintahan.

\section{Peran Pemerintah Daerah dalam Memberikan Dukungan Dana Kepada Perguruan Tinggi di Indonesia}

Peran pemerintah daerah dalam penyelenggaran pemerintahan yaitu untuk mempercepat terwujudnya kesejahteraan masyarakat melalui peningkatan pelayanan, pemberdayaan, dan peran serta masyarakat, serta peningkatan daya saing daerah dengan kualitas sumber daya manusianya.

Untuk mencapai penyelenggaraan pemerintah dapat dicapai dengan berbagai cara. Salah satunya ada melakukan alokasi dana untuk memberikan stimulus agar terwujudnya cita-cita satu pemerintah daerah. Alokasi dana tersebut bersumber dari Anggaran Pendapatan dan Belanja Daerah. Berdasarkan Pasal 1 angka 32 UndangUndang Pemerintahan Daerah Anggaran Pendapatan dan Belanja Daerah yang selanjutnya disingkat APBD adalah rencana keuangan tahunan Daerah yang ditetapkan dengan Perda.

Pendapatan daerah merupakan hak pemerintah daerah yang diakui sebagai penambahan nilai kekayaan bersih sedangkan Belanja Daerah merupakan kewajiban pemerintah yang diakui sebagai pengurang nilai kekayaan bersih (Fadillah, 2019). Belanja Daerah sebagai kewajiban apabila dikaitkan dengan Pasal 83 ayat (2) UU Pendidikan Tinggi dapat diasumsikan bahwa apabila pemerintah daerah dapat mengalokasikan dukungan dana pendidikan tinggi dalam APBD, maka kegiatan tersebut dapat menjadi kegiatan yang memenuhi kewajiban pemerintah sebagai pengurang nilai kekayaan bersih. Akan tetapi kata dapat di dalam Pasal 83 ayat (2) Undang-Undang Pendidikan Tinggi tesebut menimbulkan multiinterpretasi terkait dengan kapan dan bagaimana alokasi dana tersebut dapat diberikan.

Arti kata dapat menurut Kamus Besar Bahasa Indonesia (KBBI) yaitu diartikan dengan mampu, sanggup ataupun bisa. Sehingga arti kata dapat yang tercantum di dalam Pasal 83 ayat (2) Undang-Undang Pendidikan Tinggi terkait dengan kemampuan, kesanggupan ataupun kebisaan suatu pemerintah daerah untuk memberikan dukungan dana kepada perguruan tinggi. Apabila pemerintah daerah merasa belum sanggup, mampu ataupun bisa, maka alokasi dana kepada perguruan tinggi tersebut dapat tidak dilakukan. Hal ini dikarenakan prioritas utama kewenangan pendidikan tinggi berada di tangan Pemerintah Pusat yang dalam hal ini dilaksanakan oleh Kementerian yang membidangi urusan pemerintahan di bidang pendidikan. Berdasarkan Pasal 7 ayat (1) dan (2), Menteri bertanggung jawab atas penyelenggaraan Pendidikan Tinggi mencakup pengaturan, perencanaan, pengawasan, pemantauan, dan evaluasi serta pembinaan dan koordinasi.

Untuk memberikan jawaban terkait dengan kapan pemerintah daerah dapat mengalokasikan dana kepada perguruan tinggi adalah ketika pemerintah daerah tersebut memiliki kesanggupan, kemampuan ataupun kebisaan yang sesuai dengan nilai kekayaan daerahnya. Kemudian terkait dengan bagaimana alur ataupun mekanisme pemberian dana kepada perguruan tinggi yaitu dengan mekanisme penetapan APBD sesuai dengan peraturan perundang-undangan. Oleh karena APBD ditetapkan oleh sebuah Perda, maka penyusunan APBD menjadi tugas Bupati/ Walikota ataupun Gubernur bersama DPRD tingkat I/II sesuai dengan tugas dan wewenang yang diberikan Undang-Undang Pemerintahan Daerah.

Untuk mengetahui dan mengukur sejauh mana efektivitas dari sebuah hukum, khususnya Pasal 83 ayat (2) Undang-Undang Dikti, maka hal pertama yang dilakukan adalah mengukur sejauh mana hukum itu ditaati oleh yang menjalankan hukum itu sendiri. Setelah diperoleh ukuran mengenai ketaatannya, maka akan ditemukan jawaban bahwa aturan hukum yang bersangkutan adalah efektif atau tidak efektif.

Namun demikian, walaupun suatu aturan 
hukum terlihat efektif, tetap dimungkinkan untuk mempertanyakan dan menguji lebih jauh derajat efektivitasnya karena seseorang menaati atau tidak suatu aturan hukum tergantung pada kepentingannya.

Apabila yang akan dikaji adalah efektivitas perundang-undangan atau substansi hukumnya, maka ada beberapa faktor, yaitu; (Achmad, 2009)

a. Pengetahuan tentang substansi perundang-undangan;

b. Cara-cara untuk memperoleh pengetahuan tersebut;

c. Institusi yang terkait dengan ruang lingkup perundang-undangan didalam masyarakatnya;

d. Bagaimana proses lahirnya suatu perundang-undangan, yang tidak boleh dilahirkan secara tergesa-gesa untuk kepentingan instan (sesaat).

Pengetahuan terhadap isi undang-undang baik itu dari pemerintah daerah maupun perguruan tinggi seyogyanya sebagai instansi pelaksana sudah terbiasa menjalakan perintah peraturan perundang-undangan. Pengetahuan terhadap suatu aturan didapat dengan membaca, mempelajari serta memahami perintahnya. Selain memahami perintahnya mengetahui latar belakang dari lahirnya suatu aturan dapat memberikan pengetahuan terhadap arah maupun politik hukum dari adanya aturan tersebut. Sehingga apabila melihat Pasal 87 ayat (2) Undang-Undang Pendidikan Tinggi, peraturan ini memberikan perintah dan kesempatan bagi pemda untuk memberikan bantuan dana kepada pendidikan tinggi. Sehingga apabila dilihat dari efektivitas peraturannya, sudah sangat efektif dilihat dari substansi hukumnya

Peran yang dapat dilakukan pemerintah dalam memberikan bantuan dana pada perguruan tinggi antara lain;

\section{Pemerintah daerah sebagai regulator}

Pemerintah daerah sebagai regulator adalah menyiapkan arah penyelenggaraan pembangunan melalui peraturan-peraturan. Sebagai regulator, pemerintah daerah melakukan segala tindakannya kepada masyarakat atas dasar hukum. Pada prinsipnya peran regulator adalah peran pemerintah daerah dalam membuat aturan, terkait dengan memberikan bantuan dana kepada perguruan tinggi pemerintah daerah wajib menuangkan di dalam regulasi dalam hal ini Perda ABPD;

\section{Pemerintah daerah sebagai dinamisator}

Peran pemerintah daerah sebagai dinamisator adalah peran pemerintah daerah dalam menggerakkan partisipasi masyarakat jika adanya hambatan dalam pembangunan baik itu fisik maupun non-fisik. Pemerintah daerah berperan melalui pemberian informasi, edukasi serta arahan secara efektif kepada masyarakat. Sebagai dinamisator dalam hal pemberian bantuan dana kepada perguruan tinggi dapat diwujudkan dengan bantuan beasiswa ke mahasiswa yang memiliki kendala keuangan dalam melangsungkan pendidikan;

\section{Pemerintah daerah sebagai fasilitator}

Pemerintah daerah sebagai fasilitator yaitu menciptakan fasilitas baik itu fisik maupun nonfisik kepada masyarakat. Menciptakan fasilitas dari yang belum ada menjadi ada atau yang sudah ada menjadi lebih baik. Sebagai fasilitator pemerintah daerah dapat memberikan fasilitas penunjang di wilayahnya seperti menyediakan tempat-tempat WI-FI/Hotspot gratis, sehingga dapat memberikan stimulus kepada mahasiswa dalam mengembangan diri.

\section{IV.SIMPULAN}

Melihat posisi dari perguruan tinggi yang berada di lingkungan pemerintah daerah sebagai Aset Daerah, Partner Strategis dan Center of Excellent, menciptakan situasi \& kondisi yang sangat menguntungan bagi pemerintah daerah. Situasi yang menguntungkan tersebut dapat dirasakan dengan melihat perputaran ekonomi yang besar, jika ada perguruan tinggi yang tentunya memiliki banyak mahasiswa. Selain faktor ekonomi, faktor sosial dan budaya juga sangat berpengaruh. Datangnya mahasiswa luar daerah tentu akan dibarengi dengan masuknya nilai-nilai sosial budaya yang baru, sehingga mengakibatkan adanya pertukaran budaya yang positif. Kemudian dalam pengembangan IPTEK, pemerintah daerah dapat bersinergi dengan lembaga perguruan tinggi dalam mengembangkan IPTEK. Sehingga lembaga pendidikan tinggi selain menjadi aset juga menjadi partner strategis pemerintah. Selain itu arti kata dapat di dalam Pasal 83 ayat (2) Undang-Undang Pendidikan Tinggi diartikan sebagai situasi pemerintah daerah yang dalam mampu, sanggup ataupun bisa untuk memberikan bantuan dana kepada perguruan tinggi. Jika pemerintah daerah merasa 
belum sanggup, mampu ataupun bisa, maka alokasi dana kepada perguruan tinggi tersebut dapat tidak dilakukan.

Untuk menjalankan rencana tersebut, pemerintah daerah sesuai dengan yang di amanatkan Undang-Undang Pendidikan Tinggi Pasal 83 ayat (2) diberikan kewenangan atributif untuk memberikan bantuan dana kepada perguruan tinggi. Bantuan dana tersebut dapat terealisasikan apabila dana yang digunakan pemerintah diambil dari APBD. Dilihat dari sisi efektivitas hukumnya, secara substansi aturan pasal 87 ayat (2) Undang-Undang Pendidikan Tinggi sudah sangat efektif mengingat pemerintah daerah merupakan institusi yang sudah terbiasa mengimplementasi aturan perundang-undang. Akan tetapi ada beberapa peran tambahan yang dapat digunakan pemerintah dalam mensukseskan bantuan dana tersebut yaitu, Pemeran Pemerintah sebagai Regulator, Dinamisator dan Fasilitator.

\section{DAFTAR PUSTAKA}

Achmad, A. (2009). Menguak Teori Hukum (Legal Theory) dan Teori Peradilan (Judicialprudence) Termasuk Interpretasi Undang-Undang (Legisprudence). Jakarta: Kencana.

Fadillah, A. (2019). Penganggaran di Pemerintah Daerah (dalam Perspektif Teorits, Normatif, dan Empiris). Malang: UB Press.

Fajjlurahman, J. (2019). Hukum Tata Negara Indonesia. Jakarta: Kencana.

Marzuki, P. M. (2005). Penelitian Hukum. Jakarta: Kencana.

Nulhaqim, S. A., Heryadi, R. D., Pancasilawan, R., \& Fedryansyah, M. (2016). Peranan Perguruan Tinggi Dalam Meningkatkan Kualitas Pendidikan di Indonesia untuk Menghadapi ASEAN Community 2015. SHARE: SOCIAL WORK JURNAL, 6(2).

Winanrno, B., \& Nur. (2008). Penyalahgunaan Wewenang dan Tindak Pidana Korupsi,. Yogyakarta: laksbang mediatama. 